\title{
Removal of Microbes from Hospital Wastewater Using Neem Husk and Cake Activated Carbon
}

\author{
Alau Kenneth ${ }^{1 *}$, Gimba Casimir Emmanuel', Agbaji Bolanle Edith¹, Abechi Eyije Stephen ${ }^{1}$, Hajara Omenesa ${ }^{1}$, Emeka Nwankwere ${ }^{1}$ and \\ Yilleng Moses Titus ${ }^{2}$ \\ ${ }^{1}$ Department of Chemistry, Ahmadu Bello University, Zaria, Nigeria \\ ${ }^{2}$ Department of Chemistry, Kaduna State University, Nigeria
}

\begin{abstract}
Biowaste from neem (Azadirachta indica) were used to prepare activated carbon using $\mathrm{ZnCl}_{2}$ and $\mathrm{H}_{3} \mathrm{PO}_{4}$ as activating agents. The efficiency of the prepared adsorbents; Neem Husks activated with $\mathrm{ZnCl}_{2}(\mathrm{NHZ}), \mathrm{Neem}$ Husks activated with $\mathrm{H}_{3} \mathrm{PO}_{4}(\mathrm{NHH})$, Neem Seed activated with $\mathrm{ZnCl}_{2}(\mathrm{NCZ})$ and Neem seed activated with $\mathrm{HPO}_{4}(\mathrm{NCH})$ to remove microbes from wastewater were evaluated. The effect of initial volume of wastewater and time of exposure of the wastewater to the prepared activated carbons were studied and related to the performance of the adsorbents. The result shows high performance of the adsorbents in microbial load reduction. The bacterial load was greatly reduced by $99.4 \%\left(2600 \mathrm{CFU} / 100 \mathrm{~cm}^{3}\right), 99.3 \%\left(3000 \mathrm{CFU} / 100 \mathrm{~cm}^{3}\right), 99.3 \%\left(3100 \mathrm{CFU} / 100 \mathrm{~cm}^{3}\right)$ and $99.3 \%(2800 \mathrm{CFU} / 100$ $\mathrm{ml}$ ) by the $\mathrm{NCZ}, \mathrm{NCH}, \mathrm{NHZ}$ and $\mathrm{NHH}$ samples respectively. The fungal load was also decreased significantly by $\mathrm{NCZ}$, $\mathrm{NCH}, \mathrm{NHZ}$ and $\mathrm{NHH}$ samples to $88.75 \%\left(2700 \mathrm{CFU} / 100 \mathrm{~cm}^{3}\right), 90.0 \%\left(2400 \mathrm{CFU} / 100 \mathrm{~cm}^{3}\right), 85.83 \%(3400 \mathrm{CFU} / 100$ $\mathrm{cm}^{3}$ ) and $90.42 \%\left(2300 \mathrm{CFU} / 100 \mathrm{~cm}^{3}\right)$ respectively. NCZ was the most effective of the prepared carbon, with a $99.4 \%$ reduction of the bacterial load.
\end{abstract}

Keywords: Azadirachta indica; Activated carbon; Microbial load; Adsorption

\section{Introduction}

The basic role of health care system is providing health facilities to the patients in the society [1]. However, during diagnosis and treatment of patients, various wastes are generated which could be infectious [2]. Hospital waste is waste generated during the diagnosis, treatment, or immunization of human beings or animals or in research activities in these fields or in the production or testing of biological [3]. It has been roughly estimated that of the $4 \mathrm{~kg}$ of waste generated in a hospital at least $1 \mathrm{~kg}$ would be infected [3]. Hospital waste can be classified into infectious and non-infectious wastes.

Hospital wastewater may include water from anatomical waste, cultures, discarded medicines, and chemical wastes, body fluids, and human excreta. This wastewater may drain directly into major watersheds, and this can have serious impacts on the quality of environment in the vicinity and also on the health of people. Pathogens contained in such water can cause a variety of illnesses. Contamination of water supply from untreated healthcare waste can therefore have a devastating effect and can create and extend epidemics [4]. Infectious wastes contain pathogens in quantities sufficient to transmit infectious diseases on exposure to them. Health care waste is also categorized as non-hazardous (non-risky) and hazardous (risky) wastes. A hazardous waste may be toxic, genotoxic, corrosive, shock sensitive, flammable, reactive, explosive, radioactive, containing infectious agents and/ or sharps. In 1999, WHO classified healthcare waste into two broad categories, the first is the Communal Waste which comprises of all solid waste not including infectious, chemical, or radioactive waste. This waste stream can include items such as packaging materials and office supplies. Generally, this stream can be disposed of in a communal land fill or other such arrangement. Segregation of materials which are able to be reused or recycled will greatly reduce the impact burden of this waste stream. The second category is called the Special Waste which consists of several different subcategories: Infectious, Anatomic, Pharmaceutical, Genotoxic, Chemical, Heavy Metals, Pressurized containers and Radioactive materials.

In recent times, several methods were adopted for treatment of wastewaters. However, adsorption onto activated carbon offers the most effective and affordable approach to wastewater management
[5]. Because of the high cost of the commercial adsorbents, researchers developed different methods for the modification of low cost adsorbents that compete favourably with the commercial adsorbents. Some of the low cost materials used in the past as precursor for preparing activated carbon include; coconut shell, rice husk, corn cob and groundnut shells. Also, the treatment of wastewater and contaminated groundwater using activated carbon is increasing throughout the world as a result of the limited sources of water supply [6]. In such treatments, activated carbon is normally used as a primary treatment, preceding other purification processes, or as a final tertiary or advanced treatment. The research work aimed at preparing activated carbon from neem (Azadirachta indica) and to investigate the capacity of the activated carbons for removing microbe from hospital wastewater.

\section{Materials and Methods}

Neem husks and cakes collected from the National Research Institute for Chemical Technology (NARICT) Zaria were used to prepare the activated carbon samples. Wastewater sample used was obtained from University of Abuja Teaching Hospital (UATH), Abuja Nigeria, after certification approved by the Hospital Ethical Committee. All reagents used were of analytical grade and no further purification was carried out before use.

\section{Neem sample preparation}

Preparation of the Neem samples were carried using the methods employed in Omonhenle et al. [7] and Itodo et al. [8]. The Neem husk and cake collected were sundried for three days. The sundried samples were properly washed under running tap to remove dust and water-

*Corresponding author: Alau Kenneth, Department of Chemistry, Ahmadu Bello Univeristy, Zaria, Nigeria, Tel: +234-803-800-2812; E-mail: kennethalau@yahoo.com

Received October 16, 2015; Accepted November 30, 2015; Published December 04, 2015

Citation: Kenneth A, Emmanuel GC, Edith AB, Stephen AE, Omenesa H, et al (2015) Removal of Microbes from Hospital Wastewater Using Neem Husk and Cake Activated Carbon. Mod Chem appl 3: 171. doi:10.4172/2329-6798.1000171

Copyright: @ 2015 Kenneth A, et al. This is an open-access article distributed under the terms of the Creative Commons Attribution License, which permits unrestricted use, distribution, and reproduction in any medium, provided the original author and source are credited. 
soluble impurities. Excess water accumulated during washing were allowed to drain, in open air for another 12 hours after which they were introduced into a laboratory oven set at $105^{\circ} \mathrm{C}$ and dried for a 24 hours. The dried samples were gently crushed using a ceramic laboratory mortar and pestle followed by sieving with a $<400 \mu \mathrm{m}$ aperture sieve. The samples were stored in airtight containers for further use.

\section{Carbonization and chemical activation of neem samples}

The prepared Neem seeds and husks samples were carbonized using the methods described by Gimba et al. [9] with a few modifications. About $50 \mathrm{~g}$ of the Neem husks and seed samples were placed in large sized ceramic crucibles and carbonized at $350^{\circ} \mathrm{C}$ in a muffle furnace. The samples were removed after 8 hours of heating and allowed to cool in desiccators prior to activation. Chemical activation of the carbonized samples was done using $1 \mathrm{M}$ of $\mathrm{ZnCl}_{2}$ and $\mathrm{H}_{3} \mathrm{PO}_{4}$ as activating agents using the method of Abechi et al. [10]. The carbonized samples were impregnated with the activating agents at room temperature. A carefully weighed amount $50 \mathrm{~g}$ of the carbonized samples were placed in separate beakers containing each activating agents. The contents of each beaker were thoroughly mixed and slightly heated until it forms a paste. The paste was then transferred into crucibles which was placed in the furnace and heated at $400^{\circ} \mathrm{C}$ for 2 hours and then the temperature elevated to $600^{\circ} \mathrm{C}$ for 4 hours. The activated carbon samples were then allowed to cool in a desiccator prior to washing severally with hot distilled water. The washed samples were oven dried at $105^{\circ} \mathrm{C}$ for 6 hours to constant weight. This was then sieved to particle size of 400 $\mu \mathrm{m}$ using laboratory sieves. The fine sieved samples were stored in a clean airtight container for further studies.

$\mathrm{NHZ}$ - Neem Husk activated with $\mathrm{ZnCl}_{2}$

$\mathrm{NHH}$ - Neem Husk activated with $\mathrm{H}_{3} \mathrm{PO}_{4}$

$\mathrm{NCZ}$ - Neem Cake activated with $\mathrm{ZnCl}_{2}$

$\mathrm{NCH}$ - Neem Cake activated with $\mathrm{H}_{3} \mathrm{PO}_{4}$

\section{Column adsorption studies}

Fixed bed columns were prepared by dry packing technique, where cylindrical borosilicate glass columns (diameter- $2.4 \mathrm{~cm}$, length- 32.2 $\mathrm{cm}$, volume- about $150 \mathrm{ml}$ ) mounted vertically were packed with about $10 \mathrm{~g}$ each of the prepared activated carbon (i.e., about $12 \mathrm{ml}$ column volume) from the top of the column and allowed to settle by gravitational force. The bottom part of the adsorbent in the column was packed small amounts with nonreactive glass wool, using distilled water, to a column height of approximately $0.5 \mathrm{~cm}$ column height to prevent the adsorbents from blocking the tap of the column and returning to the treated water samples. The column with the adsorbent was washed with $10 \mathrm{~mL}$ of distilled water prior to introduction of the wastewater samples to the column. Approximately $50 \mathrm{~mL}$ of the wastewater was transferred into the column containing activated carbon and allowed to have contact with the adsorbent for 30 minutes. The adsorbent was kept submerged throughout the runs to avoid air entrapment in the bed. After the contact time had elapsed, the tap of the column was let open and the treated water (filtrate) allowed to drain and was collected in a beaker, measured and transferred into samples bottles prior to analysis $[11,12]$.

\section{Microbial analysis}

The microbiological analyses were carried out immediately after sample collection and after each treatment process and determined using pour plate technique at the Department of Microbiology, Ahmadu Bello University, Zaria. Total heterotrophic bacterial and fungal counts for the raw and treated wastewater samples were enumerated by spread plate method as described in Uzoigwe and Okpokwasili [11] and Adesemoye et al. [12]. An aliquot (1 mL) of the wastewater was transferred into $9 \mathrm{~mL}$ of distilled water and diluted serially in ten folds (10-2 to 10-5) according to the method of Adesemoye et al. [12]. Then $0.1 \mathrm{~mL}$ aliquots of the serially diluted samples were plated in duplicate plates of molten Nutrient Agar (NA) and Saboraud Dextrose Agar (SDA) at $45^{\circ} \mathrm{C}$ for the isolation and enumeration of total aerobic bacteria and fungi respectively. They were swirled to mix and colony counts were taken after incubating the plates at $37^{\circ} \mathrm{C}$ for 48 hours for the bacterial count and at ambient laboratory temperature for 5 days for the fungal count. After the incubation period, the total bacterial colonies and total fungal count which developed on the plates were enumerated, multiplied by 10 and by the dilution factors, and the results expressed as the number of ColonyForming Units (CFU/mL) of samples.

NB: The bacterial and fungal loads were determined to ascertain the effectiveness of the neem carbons on reducing microbial load. However, the bacteria and fungi were not isolated to specify which of the bacteria or fungi were adsorbed most or least.

\section{Discussion}

The results of the bacteriological and fungal analysis of the treated wastewater samples are shown in Figure 1. The NIS limits for bacterial and fungal count is $0 \mathrm{CFU} / 100 \mathrm{~mL}$ while the permissible limit for discharge of bacterial and fungal count in wastewater is $10,000 \mathrm{CFU} / 100$ $\mathrm{mL}$. The bacteriological and fungal count of the raw wastewater was exceedingly high at 4,270 and 2,400 CFU/100 mL respectively. Arvin [13] noted that high counts of bacterial load are a reflection of high level of pollution. The bacterial load was greatly reduced by 99.4\% (2600 CFU/100 mL), 99.3\% (3000 CFU/100 mL), 99.3\% (3100 $\mathrm{CFU} / 100 \mathrm{~mL}$ ) and $99.3 \%(2800 \mathrm{CFU} / 100 \mathrm{~mL})$ by the NCZ, NCH, NHZ and NHH samples respectively (Figure 1). The fungal load was also decreased significantly by the NCZ, NCH, NHZ and NHH samples to 88.75\% (2700 CFU/100 mL), 90.0\% (2400 CFU/100 mL), 85.83\% (3400 CFU/100 mL) and $90.42 \%(2300 \mathrm{CFU} / 100 \mathrm{~mL})$ respectively [14].

\section{The effect of time on microbial load of the wastewater}

The effect of contact time was investigated by varying the time (flow rate) at which the wastewater samples stayed in the columns contacting the activated carbon materials. The time on investigation ranged from 10 to 30 minutes on each of the activated carbon materials. The effect of time on the microbial load of the treated water samples are presented in Figures 2 and 3. Figure 2 shows that the bacterial load of the samples decreases significantly by over $99 \%$ of its original amount. The first 10 minutes of contact was sufficient to rapidly reduce the bacterial load. Subsequent time did not show any significant change relative to the amount reduced in the first 10 minutes of contact. The same effect and pattern is seen in Figure 3, where the fungal load of the raw waste water has been reduced by over $98 \%$. These results suggest that the activated carbon samples may have strong antimicrobial properties.

\section{Effects of wastewater volume on performance of the adsorbents}

The effects of volume of wastewater on the adsorption capacity of each of the tested activated carbon were carried out by varying the amount of wastewater that passed through the column and made contact with the activated carbon. The four neem carbons have similar trend in the adsorption of the microbial parameters. The most effective initial volume for the adsorption of bacterial and fungal load is at $10 \mathrm{~cm}^{3}$. The neem carbons were efficient in adsorbing high bacterial and fungal load in the wastewater at initial volume of $10 \mathrm{~cm}^{3}$ and thereafter the amount adsorbed remain virtually constant as presented in Figures 4 and 5. 


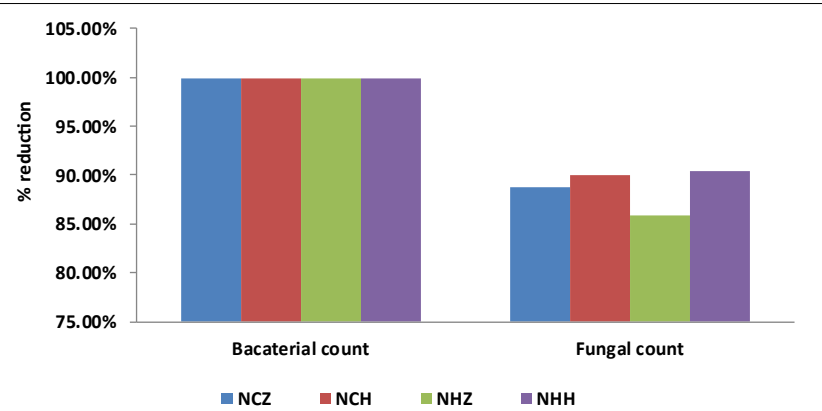

Figure 1: Percent reduction in bacterial and fungal count.

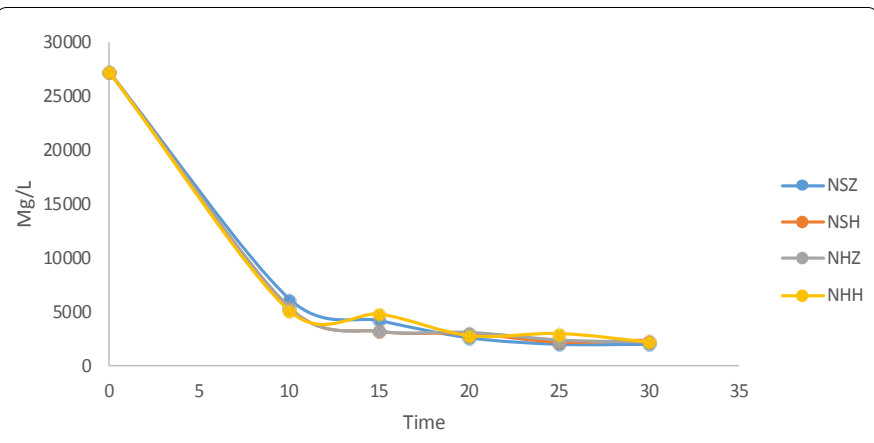

Figure 2: The effect of contact time on the bacterial load of treated wastewater.

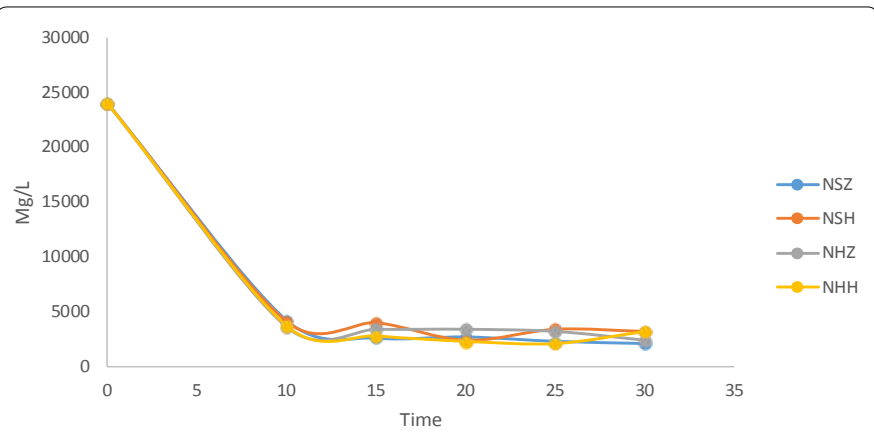

Figure 3: The effect of contact time on fungal load of treated wastewater.

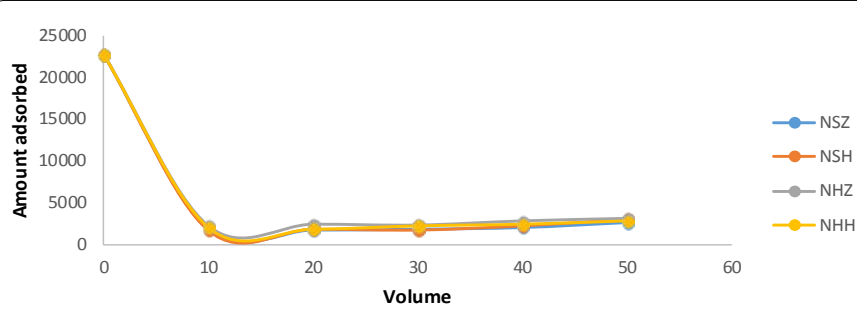

Figure 4: Effect of volume on bacterial load

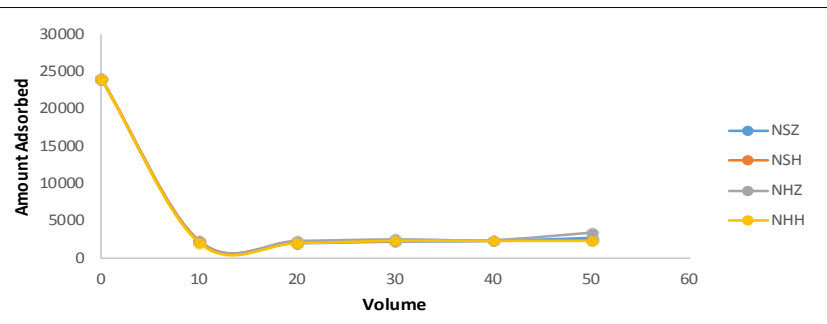

Figure 5: Effect of initial volume on fungal load.

\section{Conclusion}

Neem husk and cake are readily available bio resource materials and usually classified as waste materials. The adsorbents prepared from this biomass (NCH, NCZ, NHZ and $\mathrm{NHH}$ ) show excellent capability to remove microbes, from hospital wastewater. The bacterial load was greatly reduced by $99.94 \%$ while the fungal load was reduced by $90.42 \%$. The studies show that the prepared adsorbent is effective and could be used to remove microbes from a multi-component system such as hospital and industrial waste. The first 10 minutes of contact of the wastewater and the prepared activated carbon was sufficient to rapidly reduce the bacterial and fungal load by over $90 \%$.

\section{References}

1. Mumtaz H, Mirza MM (2014) Awareness about Hospital Wastes and its effects on the Health of Patients in District Dera Ghazi Khan. Asian J Appl Sci Eng 3: 301-308.

2. Patil GV, Pokhrel K (2005) Biomedical solid waste management in an Indian hospital: a case study. Waste Manag 25: 592-599.

3. Coker AO, Sangodoyin AY, Ogunlowo OO (1998) Managing hospital wastes in Nigeria. 24th WEDC Conference: Sanitation and Water for All.

4. Rhodes G, Huys G, Swings J, McGann P, Hiney M, et al. (2000) Distribution of oxytetracycline resistance plasmids between aeromonads in hospital and aquaculture environments: implication of $\mathrm{Tn} 1721$ in dissemination of the tetracycline resistance determinant tet A. Appl Environ Microbiol 66: 38833890 .

5. Hajira H, Muhammed S (2008) Removal of fast green dye from an aqueous solution using Azadirachta indica leaf powder as low cost adsorbent. Afr $\mathrm{J}$ Biotechnol 7: 3906-3911.

6. Meidl JA (1997) Responding to changing conditions: how powdered activated carbon systems can provide the operational flexibility necessary to treat contaminated groundwater and industrial wastes. Carbon 35: 1207-1216.

7. Omomnhenle S, Ofomaja A, Okiemen FE (2006) Sorption of methylene blue by unmodified and modified citric acid saw dust. Chemical society of Nigeria 30: $161-164$.

8. Itodo AU, Abdulrahman FW, Hassan LG, Maigandi SA, Happiness UO (2009) Estimation of the type of adsorption, sorbent saturation capacities and heat of sorption of poultry droppings activated carbon animalis. International journal of Natural and Applied sciences 5: 92-97.

9. Gimba C, Ocholi O, Nok A (2004) Preparation of Activated Carbon from Agricultural wastes II. Cyanide binding with activated carbon matrix from groundnut shell. Nig Journal of Scientific Research 4: 106-110.

10. Abechi ES, Gimba CE, Uzairu A, Kagbu JA (2011) Kinetics of adsorption of methylene blue onto activated carbon prepared from palm kernel shell. App Sci Res 3: 154-164.

11. Uzoigwe Cl, Okpokwasili GC (2012) Biodegradation of oil spill dispersants in natural aquatic ecosystem. International Journal of Physical Sciences 7: 54775484 .

12. Adesemoye AO, Opere BO, Makinde SCO (2006) Microbial content of abattoir wastewater and its contaminated soil in Lagos, Nigeria. Afr J Biotechnol 5: 1963-1968.

13. Arvin E (1991) Biodegradation kinetics of chlorinated aliphatic hydrocarbons with methane oxidizing bacteria in an aerobic fixed biofilm reactor. Water Research 25: 873-881.

14. Townend WK, Cheeseman CR (2005) Guidelines for the evaluation and assessment of the sustainable use of resources and of wastes management at healthcare facilities. Waste Manag Res 23: 398-408. 